\title{
Serum thyrotrophin concentration: an unreliable test for detection of early hypothyroidism after thyroidectomy
}

\author{
G HENNEMANN, M VAN WELSUM, B BERNARD, R DOCTER, T J VISSER
}

British Medical fournal, 1975, 4, 129-130

\begin{abstract}
Summary
Three groups of patients who had undergone subtotal thyroidectomy for Graves's disease, toxic multinodular goitre, or euthyroid multinodular goitre 12 to 15 years before and in whom a normal serum thyroxine (T-4) level was found were each divided into two subgroups on the basis of a normal or a raised serum thyrotrophin concentration. There was no difference in mean serum T-4 concentration between patients with normal and those with raised serum thyrotrophin concentrations, and the values were similar to the mean $T-4$ values of the normal population.

The mean serum triiodothyronine values of all groups were higher than normal, but the mean values of the groups with a normal and a raised serum thyrotrophin were similar. After thyroidectomy a mildly raised serum thyrotrophin does not in itself indicate the presence of hypothyroidism.
\end{abstract}

\section{Introduction}

The significance of the serum thyrotrophin level in relation to the detection of early hypothyroidism in patients treated with radioactive iodine $\left({ }^{131} \mathrm{I}\right)$ or thyroidectomy for hyperthyroidism has been a subject of controversy recently. Some workers have suggested that a raised serum thyrotrophin after thyroidectomy

\footnotetext{
Departments of Internal Medicine III and Clinical Endocrinology, Medical Faculty, Erasmus University, Rotterdam, The Netherlands G HENNEMANN, MD, reader

$M$ VAN WELSUM, MD, research fellow B BERNARD, technician

$R$ DOCTER, biochemist and head of laboratory

T J VISSER, biochemist
}

indicates early hypothyroidism. ${ }^{1}$ " Others have concluded, however, that raised serum thyrotrophin in patients who have been treated with ${ }^{131}$ I does not always point to the development of thyroid failure. ${ }^{3-5}$

We report here on our study of thyroid hormone levels and serum thyrotrophin in 114 patients who underwent subtotal thyroidectomy for Graves's disease, toxic multinodular goitre, or euthyroid multinodular goitre.

\section{Patients and methods}

The three groups consisted of 38 patients operated on for Graves's disease a mean $( \pm$ S.D.) of $11.8 \pm 4.6$ years before; 19 patients operated on for toxic multinodular goitre $14.5 \pm 4.3$ years before; and 57 patients operated on for euthyroid multinodular goitre $15 \cdot 2 \pm$ 3.6 years before.

Serum thyroxine (T-4) was determined with the Tetrasorb kit (Abbott Laboratories, North Chicago; normal range 87.51-85.3 (mean 136.4) $\mathrm{nmol} / 1$ (6.8-14.4 (mean 10.6) $\mu \mathrm{g} / 100 \mathrm{ml}$ )); serum triiodothyronine ( $\mathrm{T}-3$ ) by radioimmunoassay ${ }^{6}$ (normal range $1.2-$ $3 \cdot 2$ (mean 2.2) $\mathrm{nmol} / 1(80-205$ (mean 143$) \mathrm{ng} / 100 \mathrm{ml})$ ); and thyrotrophin by the method of Odell et al. ' (upper limit of normal 8.2 $\mathrm{mU} / 1)$.

\section{Results}

The three groups of patients were each divided into two subgroups according to whether serum T-4 was less than or greater than 87.5 $\mathrm{nmol} /(6.8 \mu / \mathrm{g} 100 \mathrm{ml}), 87.5 \mathrm{nmol} / \mathrm{l}$ being the lower limit of normal in our laboratory. Fifteen of the 38 patients who had had Graves's disease and six of the 19 who had had toxic multinodular goitre had a serum T-4 under $87.5 \mathrm{nmol} / 1$. Remarkably, no patient who had had euthyroid multinodular goitre had subnormal serum $\mathrm{T}-4$ levels. No T-4 values above the upper limit of normal were found.

All patients with a serum T-4 of or above $87.5 \mathrm{nmol} / 1$, who were all clinically euthyroid, were subdivided into those with normal serum thyrotrophin $(\leqslant 8.2 \mathrm{mU} \mathrm{l})$ and those with raised serum thyrotrophin $(>8.2 \mathrm{mU} \mathrm{l})$. The mean serum thyrotrophin, $\mathrm{T}-3$, and $\mathrm{T}-4$ values for each subgroup are shown in the table. Statistical analysis showed that there were no differences in the mean $T-3$ and $T-4$ values between groups with normal or raised TSH. Furthermore, the mean 
Mean serum T-3,T-4, and thyrotrophin levels ( \pm S.D.) in clinically euthyroid patients with normal serum $T-4$ according to whether thyrotrophin levels were normal or raised

\begin{tabular}{|c|c|c|c|c|c|c|c|c|c|}
\hline \multirow{2}{*}{\multicolumn{2}{|c|}{ Serum thyrotrophin $(\mathrm{mU} / \mathrm{l}) \ldots$}} & \multicolumn{2}{|c|}{ Graves's Disease } & \multicolumn{2}{|c|}{ Toxic Multinodular Goitre } & \multicolumn{2}{|c|}{ Euthyroid Multınodular Goitre } & \multicolumn{2}{|c|}{ All Patients } \\
\hline & & $\leqslant 8 \cdot 2$ & $>8 \cdot 2$ & $\leqslant 8 \cdot 2$ & $>82$ & 882 & $>82$ & $\leqslant 8 \cdot 2$ & $>82$ \\
\hline $\begin{array}{l}\text { No. of patients } \\
\text { T-4 (nmol/1) .. } \\
\text { T-3(nmol/1) . } \\
\text { Thyrotrophin }(\mathrm{mU} / \mathrm{l})\end{array}$ & $\begin{array}{l}\cdots \\
\cdots \\
\cdots\end{array}$ & $\begin{array}{c}15 \\
123 \cdot 6 \div 23 \cdot 2 \\
2 \cdot 61 \div 0 \cdot 68 \\
6 \cdot 8 \pm 0.93\end{array}$ & $\begin{aligned} & 8 \\
122 \cdot 3 & +27 \cdot 0 \\
2 \cdot 86 & \pm 1 \cdot 4 \\
12 \cdot 8 & \pm 4 \cdot 2\end{aligned}$ & $\begin{array}{rl}127.4 & 9 \\
3.32 & 085 \\
5.9 & 086\end{array}$ & $\begin{array}{c}4 \\
136.4: 30.9 \\
3.04: 0.58 \\
12.6: 1.8\end{array}$ & $\begin{array}{rl}38 & \\
131.3 & =20 \cdot 6 \\
2.98 & 0.83 \\
5 \cdot 3 & \pm 5\end{array}$ & $\begin{array}{c}19 \\
1300: 180 \\
316: 057 \\
117: 28\end{array}$ & $\begin{array}{c}62 \\
128.7 \pm 21.9 \\
2.95 \pm 0.83 \\
578 \pm 1.51\end{array}$ & $\begin{array}{rl} & 31 \\
1287 & 21.9 \\
3.12 \div 0 \cdot 78 \\
12 \cdot 2 \div 3.08\end{array}$ \\
\hline
\end{tabular}

Conversion: SI to Traditional Units-T-4: $1 \mathrm{nmol} / 1 \approx 0.078 \mu \mathrm{g} / 100 \mathrm{ml} \mathrm{T}-3.1 \mathrm{nmol} / 1=65 \mathrm{ng}, 100 \mathrm{ml}$.

T-4 levels of all the groups did not differ from the mean T-4 of the normal population. The reverse was true of the T-3 levels, however, which were significantly raised above normal in all groups $(P<0.001)$.

\section{Discussion}

Our patients were divided on the basis of a normal serum T-4. Some of the patients may have had circulating T-4 levels which, though in the normal range, were perhaps suboptimal in their case since serum $\mathrm{T}-4$ in the normal population has a large range. Nevertheless, there were no differences between the mean serum T-4 level of any subgroup and that of the normal population. Because there were only a few patients in some subgroups it is perhaps more important that no differences in the mean serum $T-4$ and the normal mean serum $T-4$ were found when all patients with a raised or normal serum thyrotrophin were considered. Our results show that despite a mildly raised serum thyrotrophin no change in serum T-4 could be detected. Also, no differences in the mean $\mathrm{T}-3$ levels of the different groups were apparent, though all were significantly higher than normal.

Our findings concerning thyrotrophin and $\mathrm{T}-4$ agree with those in a study of patients treated with ${ }^{131} \mathrm{I}$ for hyperthyroidism. ${ }^{3}$ Out of 24 patients who were clinically euthyroid after treatment and had a normal protein-bound iodine (P.B.I.) 11 had raised thyrotrophin values. Four of these patients developed hypothyroidism in the next three years and the others remained euthyroid for 19 to 41 months. In the same study it was found that four out of 35 patients using thyroid hormone after treatment had raised thyrotrophin levels despite a normal serum P.B.I. In another study of patients who had been treated with ${ }^{131} \mathrm{I}$ for hyperthyroidism, the serum thyrotrophin, T-4, and P.B.I. in 66 out of 69 euthyroid patients with a raised thyrotrophin did not change over 15 months." The authors concluded that a raised thyrotrophin level after treatment with ${ }^{131}$ I for thyrotoxicosis could not be used as an indication of impending hypothyroidism. Tunbridge et al. ${ }^{4}$ found similar results in patients treated for hyperthyroidism with ${ }^{131} \mathrm{I}$; increased thyrotrophin was found in $46^{\circ}{ }_{0}$ of clinically euthyroid patients with normal serum levels of $\mathrm{T}-4$. No sign of developing hypothyroidism was seen after one year. The mean serum T-4 was not significantly different from normal, and the mean serum T-4 of patients with raised thyrotrophin levels was significantly lower than that of patients with normal thyrotrophin levels who had been treated with ${ }^{131} \mathrm{I}$. It was not stated, however, whether the serum $\mathrm{T}-4$ in the latter group was significantly higher than normal. No abnormal serum $\mathrm{T}-3$ values were found in these patients. ${ }^{+}$

Out of 60 patients treated by subtotal thyroidectomy for thyrotoxicosis and remaining clinically euthyroid one to seven years after operation 39 had a raised serum thyrotrophin level.: The mean serum T-4 of these patients was significantly lower than in those with normal thyrotrophin levels, who had serum $\mathrm{T}-4$ values similar to those in the normal population. The mean serum T-3 was similar in the groups with normal and increased serum thyrotrophin.
Hence, it is well established that many clinically euthyroid patients who have been treated for thyrotoxicosis or euthyroid multinodular goitre have a raised serum thyrotrophin. Though overt hypothyroidism has later developed in some of these patients most show no sign of deterioration of thyroid function during follow-up. Since none of these patients were followed for more than three years, however, it is possible that some will finally develop hypothyroidism. Nevertheless, from the data available it seems unwarranted to conclude that a raised serum thyrotrophin in these kinds of patients implies that hypothyroidism is present and that substitution with thyroid hormone should be started.

The fact that we, like others, ${ }^{34}$ found a normal mean serum $\mathrm{T}-4$ in clinically euthyroid patients with raised thyrotrophin levels in contrast to Evered et al.'s $s^{2}$ finding of a low mean serum $\mathrm{T}-4$ when thyrotrophin was raised may be explained by the different selection procedures. Evered et al. ${ }^{2}$ selected patients on the basis of clinical euthyroidism only, which resulted in the inclusion of four patients with subnormal $T-4$ and raised thyrotrophin values, while we required a normal serum T-4 as well. The finding of raised serum thyrotrophin with normal T-4 levels may indicate that factors other than circulating thyroid hormone may affect thyrotrophin secretion-for example, factors related to reduction in the mass of functioning thyroid tissue, as suggested by Tunbridge et al. ${ }^{4}$ Our findings of a raised T-3 level in thyroidectomized patients with or without raised thyrotrophin levels is difficult to explain. It has been suggested that in clinscally euthyroid patients after treatment a high plasma $\mathrm{T}-3 \mathrm{~T}-4$ ratio may be due to poorly iodinated thyroglobulin, ${ }^{\text {* }}$ but in that case low serum $\mathrm{T}-4$ levels would also be expected, which was obviously not the case in our study.

We thank the National Pituitary Agency, National Institutes of Health, Bethesda, for the supply of human thyrotrophin for iodination and antihuman thyrotrophin serum; the National Institute of Medical Research, Mill Hill, London, for the supply of human standard thyrotrophin; Mrs. C. C. Berger for her expert administrative help.

Requests for reprints should be addressed to G. Hennemann.

\section{References}

${ }^{1}$ Hedley, A. J., et al., Lancet, 1971, 1, 7697.

2 Evered, D., et al., British Medical fournal, 1975, 1, 25.

3 Slingerland, D. W., et al., fournal of Clinical Endocrinology and Metabolism, $1972,35,912$.

4 T unbridge, W. M. G., Harsoulis, P., and Goulden, A. W. G., British Medical fournal, 1974, 3, 89

5 Toft, A. D., et al., Lancet, 1973, 2, 644.

${ }^{6}$ Docter, R., Hennemann, G.. and Bernard, B., Israel fournal of Medical Sciences, 1972, 8, 23.

' Odell, W D., Wilber, J. F., and Paul, W E., fournal of Clinical Endocrinology and Metabolism, 1972. 35, 831

${ }^{8}$ Greer, M. A.. Mayo Clinic Prociedings, 1972, 47, 944. 